\title{
Enzymic activity of the mycoparasite Verticillium fungicola on Agaricus bisporus fruit body cell walls
}

\author{
M. Calonje, C. García Mendoza, B. Galán and M. Novaes-Ledieu
}

Author for correspondence: C. García Mendoza. Tel: +34 15611800. Fax: +3415627518.

Centro de Investigaciones Biológicas, CSIC, Velázquez 144, 28006 Madrid, Spain

\begin{abstract}
The in vitro production of different hydrolytic enzyme activities by Verticillium fungicola, a mycoparasite of Agaricus bisporus fruit bodies, was examined in cultures grown with various carbon sources (glucose, fructose, sucrose and $A$. bisporus cell walls). Several of the identified enzymes were influenced by the carbon source. The results of A. bisporus cell wall digestion by these enzymes in vitro have been compared with $V$. fungicola infection of $A$. bisporus fruit bodies in vivo. Evidence supporting mycoparasite enzymic action on the host cell walls is presented.
\end{abstract}

Keywords: Agaricus bisporus cell walls, lytic enzymes, mycoparasitism, Verticillium fungicola

\section{INTRODUCTION}

Verticillium fungicola has been found to cause dry bubble disease in crops of the white button mushroom Agaricus bisporus. The infection process is not understood because of its complexity, involving the presence of $V$. fungicola spores and subsequent interactions between the mycelium of the pathogen and A. bisporus mycelium. In a recent study North \& Wuest (1993) described the presence of $V$. fungicola hyphae growing intercellularly inside the $A$. bisporus fruit body, as previously reported by Ware (1933) and Matthews (1983). More recently Dragt et al. (1996) also found $V$. fungicola growing intracellularly in the A. bisporus fruit body hyphae.

The cell walls of the parasitized A. bisporus fruit bodies are thin in comparison to the thicker and more electrondense walls of healthy cells, supporting the view that cell-wall-degrading enzymes may play an important role in the infection process, as previously postulated by Michaels (1973), Trigiano \& Fergus (1979) and Kalberer (1984).

The cell wall of fungi is a complex structure composed of glucans $(\alpha$ and $\beta)$, glycans, chitin and lesser quantities of proteins and lipids (Bartnicki-García, 1968). Successful cell wall degradation may therefore depend on the activity of more than one enzyme. The present work was undertaken to investigate the enzymes secreted by $V$. fungicola grown on a minimal synthetic medium supplemented with glucose, fructose, sucrose or cell walls of $A$. bisporus as the sole carbon source and to investigate the effect of these extracellular enzymes on cell walls in an attempt to correlate the results with the in vivo infection process.

\section{METHODS}

Organisms and culture conditions. A. bisporus mushrooms (strain $\mathrm{H} 25$ ) were grown at $21^{\circ} \mathrm{C}$ in the Centro de Investigación, Experimentación y Servicios del Champiñon (CIES, Quintanar del Rey, Cuenca, Spain). V. fungicola var. fungicola, isolated from naturally infected mushrooms, was grown at $25^{\circ} \mathrm{C}$ and maintained on Raper agar (Raper et al., 1972).

Preparation of hyphal cell walls. A. bisporus fruit bodies, free of lamellae, were sliced and disrupted by the action of a Polytron homogenizer and the walls purified as described by Avellán et al. (1986). The cell walls were stored in a lyophilized state.

Conditions for enzyme production. $V$. fungicola was grown on minimal synthetic medium (MSM) containing $\left(\mathrm{g} \mathrm{l}^{-1}\right)$ : $\mathrm{MgSO}_{4} .7 \mathrm{H}_{2} \mathrm{O}, 0.2 ; \mathrm{K}_{2} \mathrm{HPO}_{4}, 0.9 ; \mathrm{KCl}, 0 \cdot 2 ; \mathrm{FeSO}_{4} .7 \mathrm{H}_{2} \mathrm{O}$, $0.002 ; \mathrm{MnSO}_{4}, 0.002$; and $\mathrm{ZnSO}_{4}, 0.002$. The medium was supplemented with $0.1 \%(\mathrm{w} / \mathrm{v})$ of the appropriate carbon (glucose, fructose, sucrose and $A$. bisporus cell walls) and nitrogen $\left(\mathrm{NH}_{4} \mathrm{NO}_{3}\right)$ sources. The $\mathrm{pH}$ of the medium was adjusted to $6 \cdot 3$. Flasks $(250 \mathrm{ml})$ containing $50 \mathrm{ml}$ culture medium were heat sterilized, inoculated with $V$. fungicola conidia and incubated statically at $25^{\circ} \mathrm{C}$ for various time periods ( 24 to $168 \mathrm{~h}$ ). The cultures were filtered through Whatman $3 \mathrm{MM}$ paper in a Millipore filtration apparatus, the filtrate centrifuged at $6000 \mathrm{~g}$ for $10 \mathrm{~min}$ and the supernatant extensively dialysed against distilled water at $4{ }^{\circ} \mathrm{C}$. These dialysed solutions were routinely used for enzyme assays. The enzyme solutions were then lyophilized for further analysis. 
Protein concentration was determined according to Bradford (1976) using the Bio-Rad protein assay dye reagent and BSA as a protein standard. Fungal growth was followed by determining mycelial dry weight.

Enzyme assays and substrates. Activities of 1,3- $\beta$-glucanase, $1,4-\beta$-glucanase, 1,6 - $\beta$-glucanase, 1,3 - $\alpha$-glucanase, $1,4-\alpha$-glucanase and 1,4- $\beta$-xylanase were assayed on, respectively, laminarin (Koch-Light), carboxymethylcellulose (Sigma), pustulan (Calbiochem), 1,3- $\alpha$-glucan of Aspergillus nidulans, amylose (Sigma) and xylan (Koch-Light) by measuring the release of reducing groups (Nelson, 1957). Reaction mixtures contained $33 \mu \mathrm{l}$ substrate solution $\left(5 \mathrm{mg} \mathrm{ml}^{-1}\right)$ at $\mathrm{pH} 5 \cdot 2(50 \mathrm{mM}$ sodium acetate buffer) and $33 \mu$ l enzyme solution; enzyme activity was stopped after $16 \mathrm{~h}$ at $37^{\circ} \mathrm{C}$ by adding the Nelson-Somogyi alkaline copper reagent (Somogyi, 1952). Activities (U) are expressed as $\mu \mathrm{mol}$ glucose or xylose released $h^{-1}$ as assessed from standard curves prepared for each sugar.

Chitinase activity was assayed with $60 \mu \mathrm{l}$ of $5 \mathrm{mg}$ chitin $\mathrm{ml}^{-1}$ (Sigma) in $50 \mathrm{mM}$ sodium acetate buffer $\mathrm{pH} \mathrm{5.2,} \mathrm{mixed} \mathrm{with}$ $140 \mu$ lenzyme solution. The mixture was incubated for $16 \mathrm{~h}$ at $37^{\circ} \mathrm{C}$ and the reaction was stopped by boiling for $5 \mathrm{~min}$. Samples were centrifuged at $5000 \mathrm{~g}$ for $10 \mathrm{~min}$ and $100 \mu \mathrm{l}$ supernatant was incubated with $20 \mu \mathrm{l}$ of $3 \%(\mathrm{w} / \mathrm{v})$ helicase at $37^{\circ} \mathrm{C}$ (De la Cruz et al., 1992). After $1 \mathrm{~h}$ incubation, $100 \mu \mathrm{l}$ samples were taken and the $N$-acetylglucosamine liberated was measured according to Riessig et al. (1955).

Activities of $\beta$-D-glucosidase, $\alpha$-D-glucosidase, $\beta$-D-mannosidase, $\alpha$-D-mannosidase, $\beta$-D-xylosidase, $N$-acetyl- $\beta$-D-glucosaminidase and $N, N^{\prime}$-diacetyl- $\beta$-D-chitobiosidase (chitobiosidase) were determined by measuring the rate of hydrolysis of the corresponding $p$-nitrophenylglycosides (Sigma). Reaction mixtures contained $50 \mu \mathrm{l}$ glycoside solution $\left(0.5 \mathrm{mg} \mathrm{ml}^{-1}\right.$ in $50 \mathrm{mM}$ sodium acetate buffer, $\mathrm{pH} 5 \cdot 2$ ) and $50 \mu \mathrm{l}$ enzyme solution. After $16 \mathrm{~h}$ at $37^{\circ} \mathrm{C}$ reactions were stopped by adding $0.9 \mathrm{ml} 0.37 \mathrm{M} \mathrm{Na}_{2} \mathrm{CO}_{3}$. Absorbance was measured at $410 \mathrm{~nm}$. Activities (U) are expressed as $\mu \mathrm{mol} p$-nitrophenol released by the enzyme solution $\mathrm{h}^{-1}$ at $37^{\circ} \mathrm{C}$.

Protease activity was assayed with $100 \mu \mathrm{l}$ casein solution $(1 \%$ in $50 \mathrm{mM}$ potassium phosphate buffer $\mathrm{pH} \mathrm{8.0)}$ mixed with $0.8 \mathrm{ml}$ of $0.2 \mathrm{M}$ Tris $/ \mathrm{HCl}$ buffer $\mathrm{pH} 8.0,0.3 \mathrm{ml}$ enzyme solution and distilled water to a total volume of $1 \mathrm{ml}$. The mixture was incubated for $16 \mathrm{~h}$ at $30{ }^{\circ} \mathrm{C}$. Samples were then mixed with $1.5 \mathrm{ml} 5 \%$ trichloroacetic acid, kept for $1 \mathrm{~h}$ at room temperature and then centrifuged to remove undigested casein. The absorbance of the clear supernatant was measured at $280 \mathrm{~nm}$. Activity (U) is expressed as an increase in $A_{280}$ of 0.001 under the described assay conditions.

Appropriate controls of substrates and enzyme solutions incubated separately were included in each group of activity assays.

Detection of 1,3- $\beta$-glucanase and chitinase activities on PAGE. The 1,3- $\beta$-glucanase and chitinase activities were separated by PAGE under native conditions at $\mathrm{pH} 8.9$ according to the method of Davis (1964), using $5 \%(\mathrm{w} / \mathrm{v})$ polyacrylamide stacking gel and $6-15 \%(\mathrm{w} / \mathrm{v})$ polyacrylamide gradient resolving gel, containing $0.01 \%(\mathrm{w} / \mathrm{v})$ glycol chitin synthesized from glycol chitosan (Trudel \& Asselin, 1989) in the case of chitinase activity. Chitinase activity after PAGE was identified by incubating the gel for $2 \mathrm{~h}$ at $37^{\circ} \mathrm{C}$ in $50 \mathrm{mM}$ sodium acetate buffer $\mathrm{pH} 5 \cdot 2$ and staining with calcofluor white M2R according to the method of Trudel \& Asselin (1989). Detection of $1,3-\beta$-glucanase activity after PAGE was performed by incubating the gel $2 \mathrm{~h}$ at $37^{\circ} \mathrm{C}$ with $0.6 \%(\mathrm{w} / \mathrm{v})$ laminarin in $10 \mathrm{mM}$ sodium acetate buffer $\mathrm{pH} \mathrm{5.2,} \mathrm{the}$ reducing sugars formed being detected with $0.15 \%(\mathrm{w} / \mathrm{v})$ 2,3,5-triphenyltetrazolium chloride (Sigma) in $1 \mathrm{M} \mathrm{NaOH}$ according to the method of Pan et al. (1989). All chemicals for electrophoresis were obtained from Bio-Rad.

Electron microscopy. Cell walls of $A$. bisporus fruit bodies were suspended in 0.05 $\mathrm{M}$ sodium acetate buffer $\mathrm{pH} 5.015 \mathrm{mg}$ $\left.\mathrm{ml}^{-1}\right)$ and incubated with the enzyme solutions $\left(3 \mathrm{mg} \mathrm{ml}^{-1}\right.$ in the same buffer) obtained from cell walls or fructose-grown cultures. Digestions were incubated at $37^{\circ} \mathrm{C}$ for 16,24 and $72 \mathrm{~h}$. Tissue from infected and healthy A. bisporus fruit bodies together with the digested cell walls were fixed in $2 \%(\mathrm{w} / \mathrm{v})$ glutaraldehyde in $0.1 \mathrm{M}$ phosphate buffer $\mathrm{pH} 7.0$ for $4 \mathrm{~h}$ at room temperature. The samples were washed four times with phosphate buffer and postfixed in $2 \%(\mathrm{w} / \mathrm{v})$ osmium tetroxide in the same buffer for $1 \mathrm{~h}$ at room temperature. After several washes, the samples were dehydrated in acetone and embedded in Vestopal W resin. Ultrathin sections $(50 \mathrm{~nm})$ were collected on 300-mesh copper grids coated with Formvar and stained with uranyl acetate and lead citrate. Samples were examined in a Philips EM300 transmission electron microscope.

Digestion of $A$. bisporus cell walls by the enzyme extracts obtained from fructose or A. bisporus cell wall culture medium was also quantified by gravimetric analysis.

\section{RESULTS}

\section{Enzyme production of $\boldsymbol{V}$. fungicola grown on different carbon sources}

Growth of $V$. fungicola was determined on different carbon sources (Fig. 1). Maximum growth was obtained on sucrose and glucose media compared with that obtained on fructose. Growth on medium containing $A$. bisporus cell walls was not determined because of the inability to separate the insoluble cell wall material from $V$. fungicola mycelium.

The production of $V$. fungicola lytic activities was

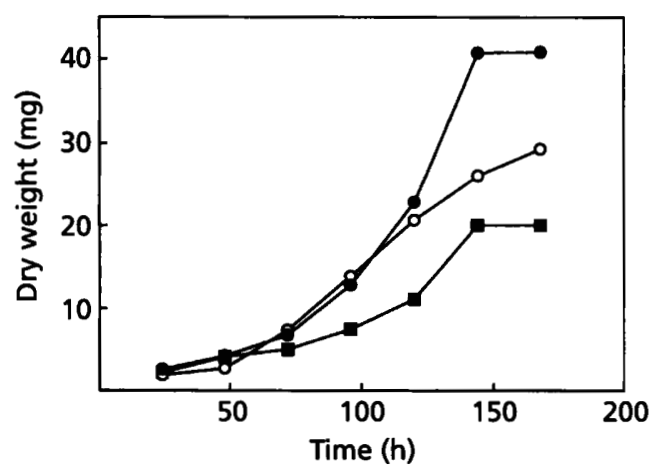

Fig. 1. Growth of $V$. fungicola on MSM supplemented with $0.1 \%(w / v)$ fructose $(\square)$, glucose $(O)$ or sucrose $(0)$ as sole carbon source. Mycelia grown on different carbon sources $\left(50 \mathrm{ml}\right.$ culture medium) were collected and dried at $60^{\circ} \mathrm{C}$. Growth was estimated as mycelial mass (mg). Each value represents the mean of three separate determinations. 

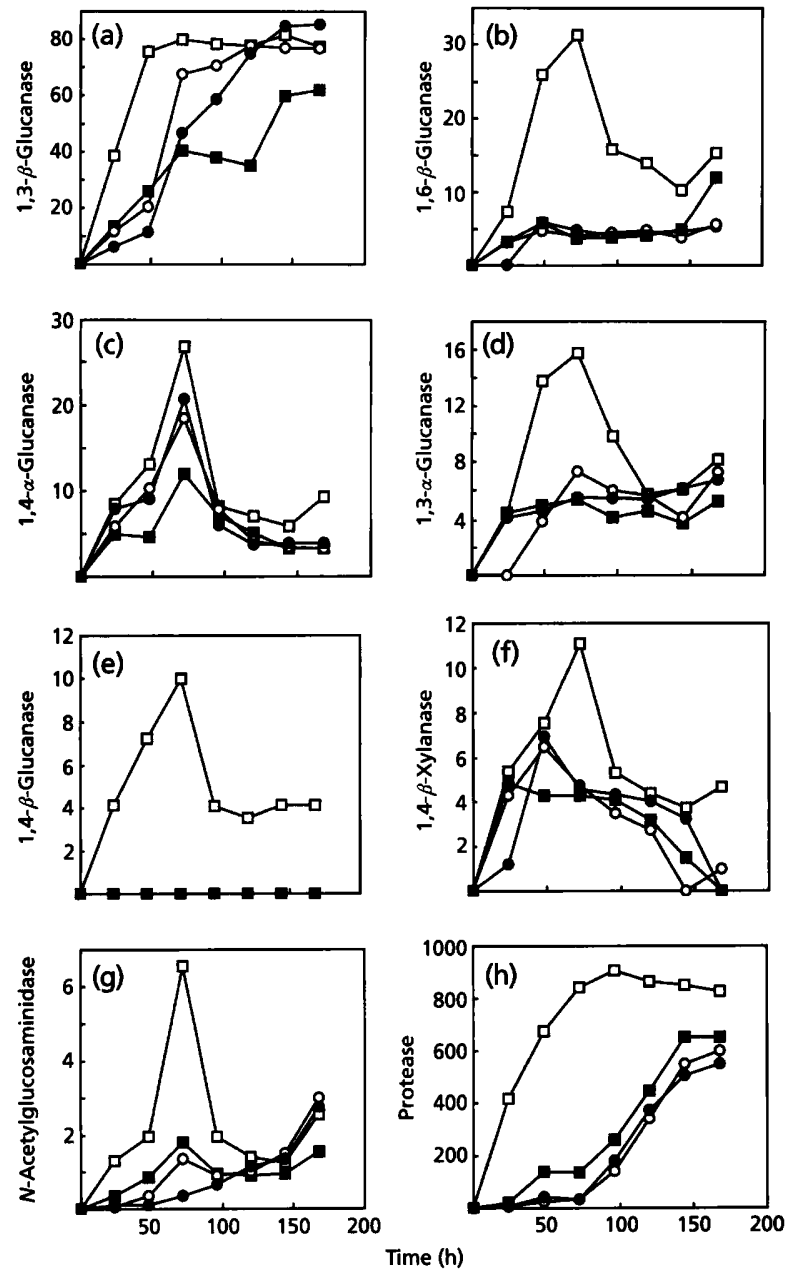

Fig. 2. Time-course curves of enzyme activities $\left(U \mathrm{ml}^{-1}\right)$ produced by $V$. fungicola growing in MSM supplemented with $0.1 \%(w / v)$ A. bisporus cell walls $(\square)$, fructose $(\square)$, glucose $(0)$ or sucrose (O) as sole carbon source. (a) 1,3- $\beta$-glucanase; (b) 1,6- $\beta$-glucanase; (c) 1,4- $\alpha$-glucanase; (d) 1,3- $\alpha$-glucanase; (e) 1,4- $\beta$-glucanase; (f) 1,4- $\beta$-xylanase; (g) $N$-acetylglucosaminidase; (h) protease.

significantly influenced by the carbon source. Fig. 2 shows the time course of (a) 1,3- $\beta$-glucanase, (b) 1,6- $\beta$ glucanase, (c) 1,4- $\alpha$-glucanase, (d) 1,3- $\alpha$-glucanase, (e) 1,4- $\beta$-glucanase, (f) 1,4- $\beta$-xylanase, (g) $N$-acetylglucosaminidase and (h) protease production by $V$. fungicola mycelia grown in synthetic medium supplemented with $0.1 \%(\mathrm{w} / \mathrm{v})$ A. bisporus cell walls, fructose, glucose or sucrose. Whereas 1,3- $\beta$-glucanase and 1,4- $\alpha$-glucanase were, remarkably, detected with all the carbon sources used, the other activities were only significantly produced with $A$. bisporus cell walls $(1,4-\beta$-glucanase was induced only in this medium). Proteolytic and 1,3- $\beta$ glucanase activities were induced earlier in the medium containing A. bisporus cell walls than in the media with other carbon sources. The maximum extracellular protein production and the highest enzyme activities were obtained after $72 \mathrm{~h}$ incubation in all cases. Noninoculated cell wall medium contained some basal protein $\left(0.9 \mu \mathrm{g} \mathrm{ml}^{-1}\right)$. This protein may have come from fragments that were released from the cell walls by heat sterilization. However, after $72 \mathrm{~h}$ of $V$. fungicola growth the protein reached $3.1 \mu \mathrm{g} \mathrm{ml}^{-1}$ in the same medium but a part of the basal protein could have been digested by the action of the parasite. The fructose, glucose and sucrose media after $72 \mathrm{~h}$ of $V$. fungicola growth contained $1 \cdot 1,2 \cdot 5$ and $2 \cdot 0 \mu \mathrm{g}$ protein $\mathrm{ml}^{-1}$, respectively.

The production of $\beta$-D-glucosidase, $\alpha$-D-glucosidase, $\beta$ $\mathrm{D}$-xylosidase, $\beta$-D-mannosidase, chitobiosidase and $N$ acetylglucosaminidase together with endolytic activities were also determined (Table 1). $\beta$-D-Glucosidase and $\alpha$ $D$-glucosidase activities were detected in all the culture media whereas $\beta$-D-xylosidase and chitobiosidase were found only in media containing cell walls and fructose; chitobiosidase activity was considerably greater in the medium containing cell walls. Maximum specific activities [U (mg extracellular protein) ${ }^{-1}$ ] of the enzymes assayed (Table 1) were obtained when the carbon source was $A$. bisporus cell walls, except in the case of $1,3-\beta$ glucanase, $1,4-\alpha$-glucanase and 1,4- $\beta$-xylanase, which reached their maximum values in medium containing fructose as the carbon source.

\section{Native PAGE}

PAGE analysis of the $V$. fungicola protein extracts obtained in different culture media (Fig. 3a) revealed that the mycoparasite presents different protein patterns depending on whether it is growing on A. bisporus cell walls or on glucose, sucrose or fructose. Extract from non-inoculated cell wall medium used as control did not show any distinct band when analysed by electrophoresis (Fig. 3a, lane 0). Three (A-C) and seven (A-G) bands corresponding to, respectively, $1,3-\beta$-glucanase and chitinase activities were developed on PAGE (Fig. $3 \mathrm{~b}, \mathrm{c})$. Depending on the carbon source used, different isoforms of both enzymes were detected. 1,3- $\beta$-Glucanase isoform $\mathrm{C}$ was only found in culture filtrates of medium containing cell walls. Isoforms A and B were detected in all culture media but were significantly increased in cell wall culture filtrate. In the case of chitinase, identical electrophoretic profiles (isoforms A and B) were detected in culture filtrates of media containing glucose, sucrose or fructose. A completely different profile (isoforms $A-G$ ) was detected in culture filtrates of medium containing A. bisporus cell walls.

\section{Electron microscopy}

Pieces of healthy and infected A. bisporus fruit bodies were examined by transmission electron microscopy. Fig. 4(a), as control, is an ultrathin section of healthy $A$. bisporus fruit body hyphae, while Fig. 4(b) shows the invasion of the host hyphae by V. fungicola. The remaining micrographs (Fig. 4c-f) show the interaction zone between $V$. fungicola and $A$. bisporus and part of the host wall where clear signs of cell wall degradation can be seen.

Fig. 5(c-h) shows the sequential degradation of isolated $A$. bisporus fruit body cell walls by the $V$. fungicola enzyme extracts (only from media with cell walls or 
Table 1. Extracellular enzyme activities produced by $V$. fungicola grown in MSM with different carbon sources

Enzyme activities were measured after $72 \mathrm{~h}$ incubation. Results are means of at least three independent experiments. U, total activity $\left(\mu \mathrm{mol} \mathrm{h}^{-1}\right) ; \mathrm{U} \mathrm{mg}^{-1}$, specific activity.

\begin{tabular}{|c|c|c|c|c|c|c|c|c|c|}
\hline \multirow[t]{3}{*}{ Enzyme activity } & \multirow[t]{3}{*}{ Substrate } & \multicolumn{8}{|c|}{ Carbon source } \\
\hline & & \multicolumn{2}{|c|}{ Cell wall } & \multicolumn{2}{|c|}{ Fructose } & \multicolumn{2}{|c|}{ Glucose } & \multicolumn{2}{|c|}{ Sucrose } \\
\hline & & $\mathrm{U}$ & $\mathbf{U} \mathbf{m g}^{-1}$ & $\mathbf{U}$ & $\mathrm{U} \mathrm{mg}^{-1}$ & $\mathrm{U}$ & $\mathrm{U} \mathbf{m g}^{-1}$ & $\mathrm{U}$ & $\mathrm{U} \mathrm{mg}^{-1}$ \\
\hline $1,3-\beta$-Glucanase & Laminarin & $63 \cdot 80$ & $405 \cdot 98$ & $31 \cdot 15$ & $551 \cdot 81$ & 53.65 & $418 \cdot 48$ & $36 \cdot 35$ & $353 \cdot 77$ \\
\hline $1,6-\beta$-Glucanase & Pustulan & $31 \cdot 35$ & $199 \cdot 49$ & $4 \cdot 85$ & $85 \cdot 91$ & $4 \cdot 10$ & $31 \cdot 98$ & $3 \cdot 75$ & 36.49 \\
\hline 1,4- $\beta$-Glucanase & CM-cellulose & $10 \cdot 00$ & $63 \cdot 63$ & 0 & 0 & 0 & 0 & 0 & 0 \\
\hline 1,3- $\alpha$-Glucanase & 1,3- $\alpha$-Glucan & $15 \cdot 75$ & $100 \cdot 22$ & $5 \cdot 35$ & $94 \cdot 77$ & $7 \cdot 35$ & $57 \cdot 33$ & $5 \cdot 50$ & 53.52 \\
\hline 1,4- $\alpha$-Glucanase & Amylose & $26 \cdot 80$ & $170 \cdot 50$ & 11.95 & $211 \cdot 69$ & $18 \cdot 45$ & $143 \cdot 91$ & $20 \cdot 7$ & $201 \cdot 45$ \\
\hline $1,4-\beta$-Xylanase & Xylan & $11 \cdot 1$ & $70 \cdot 63$ & $4 \cdot 30$ & $76 \cdot 17$ & 4.75 & 37.05 & $4 \cdot 60$ & 44.76 \\
\hline$\beta$-D-Glucosidase & $\mathrm{pNP}-\beta$-D-Glc & $7 \cdot 60$ & $48 \cdot 36$ & $1 \cdot 00$ & $17 \cdot 71$ & $0 \cdot 75$ & $5 \cdot 85$ & 0.95 & $9 \cdot 24$ \\
\hline$\alpha$-D-Glucosidase & pNP- $\alpha-D-G l c$ & 0.50 & $3 \cdot 18$ & $0 \cdot 10$ & $1 \cdot 77$ & $0 \cdot 10$ & $0 \cdot 78$ & $0 \cdot 1$ & 0.97 \\
\hline$\beta$-D-Xylosidase & pNP- $\beta-\mathrm{D}-\mathrm{Xyl}$ & 0.40 & $2 \cdot 54$ & $0 \cdot 10$ & $1 \cdot 77$ & 0 & 0 & 0 & 0 \\
\hline$\beta$-D-Mannosidase & pNP- $\beta$-D-Man & 0.45 & $2 \cdot 86$ & 0 & 0 & 0 & 0 & 0 & 0 \\
\hline Chitinase & Chitin & $6 \cdot 35$ & $40 \cdot 40$ & $0 \cdot 85$ & $15 \cdot 05$ & $0 \cdot 85$ & $6 \cdot 63$ & 0.85 & $8 \cdot 27$ \\
\hline$N$-Acetylglucosaminidase & pNP-GlcNAc & $6 \cdot 55$ & 41.67 & $1 \cdot 80$ & $31 \cdot 88$ & $1 \cdot 35$ & $10 \cdot 53$ & 0.35 & $3 \cdot 40$ \\
\hline Chitobiosidase & $\mathrm{pNP}-(\mathrm{GlcNAc})_{2}$ & $4 \cdot 00$ & $25 \cdot 45$ & $0 \cdot 1$ & 1.77 & 0 & 0 & 0 & 0 \\
\hline Protease & Casein & $841 \cdot 0$ & $5351 \cdot 5$ & $135 \cdot 25$ & $2395 \cdot 92$ & $32 \cdot 35$ & $252 \cdot 34$ & $32 \cdot 35$ & 314.84 \\
\hline
\end{tabular}

(a)

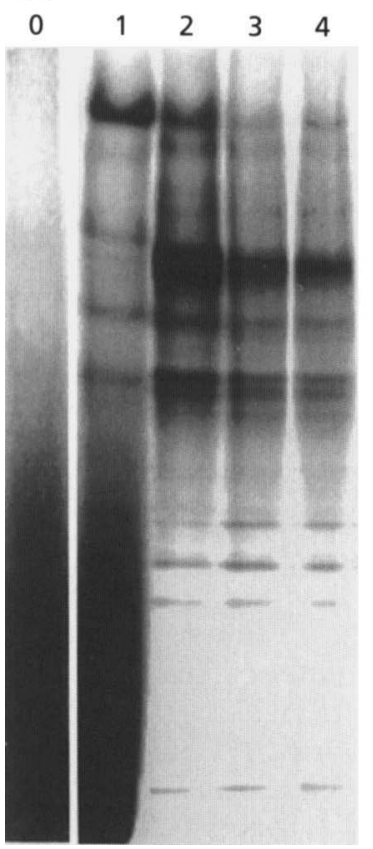

(b)

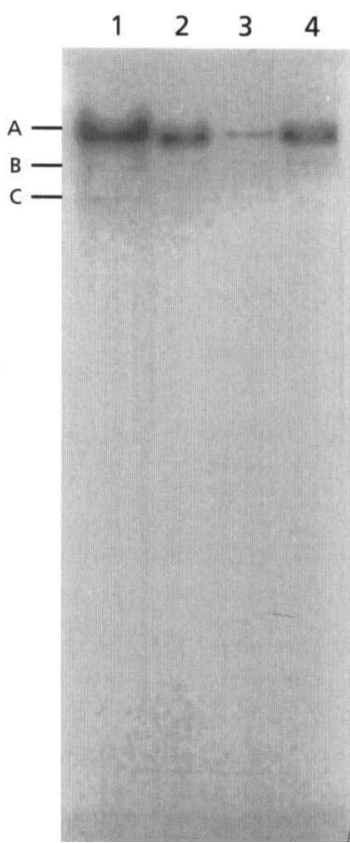

(c)

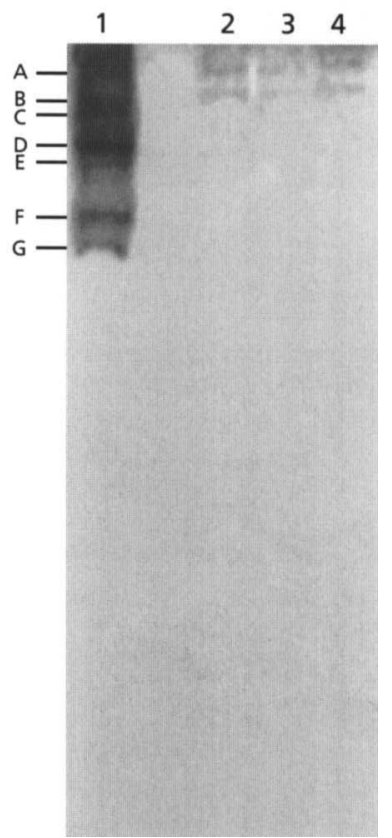

Fig. 3. PAGE (6-15\% gradient) of (a) extracellular proteins ( $85 \mu \mathrm{g}$ of each sample), (b) $1,3-\beta$-glucanase activities ( $20 \mu \mathrm{g}$ of each sample) and (c) chitinase activities $(20 \mu \mathrm{g}$ of each sample) secreted by $V$. fungicola grown on media containing either $A$. bisporus cell walls (lane 1), glucose (lane 2), sucrose (lane 3) or fructose (lane 4); non-inoculated medium containing $A$. bisporus cell walls was used as control (lane $0,70 \mu \mathrm{g}$ ).

fructose because glucose and sucrose cultures produced poorer cell wall digestions), together with the corresponding controls (Fig. 5a, b). The lytic effect of the enzyme extract obtained with $A$. bisporus cell walls appeared significantly higher than that obtained with fructose as the carbon source and this was confirmed by gravimetric analysis of the cell walls after digestion. After $16 \mathrm{~h}$ the percentage weight loss of the cell walls 

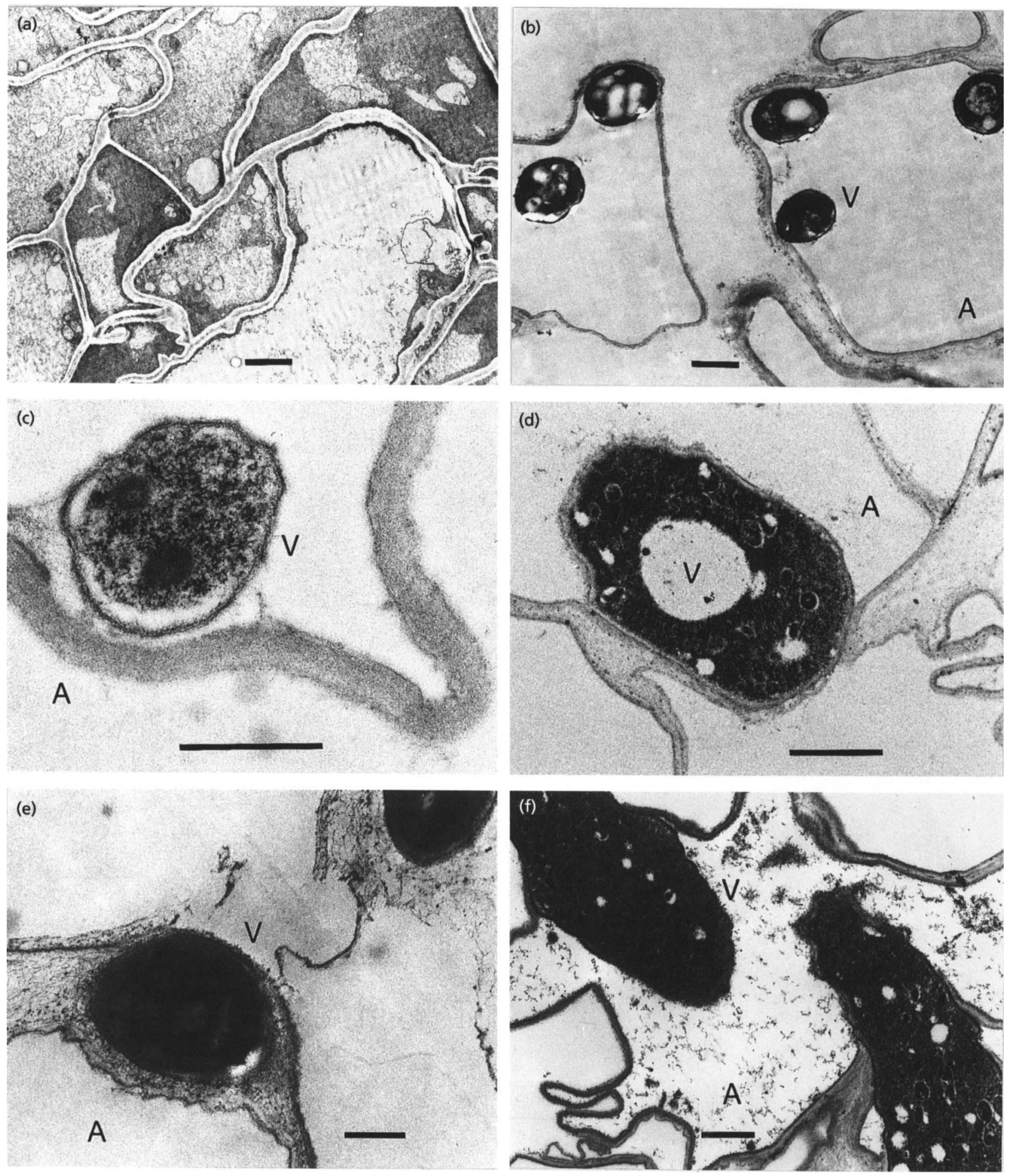

Fig. 4. Transmission electron micrographs of $V$. fungicola $(V)$ infection of $A$. bisporus (A). (a) Healthy $A$. bisporus fruit body hyphae (bar, $2 \mu \mathrm{m}$ ); (b) invasion of host hyphae by $V$. fungicola (bar, $2 \mu \mathrm{m})$; (c), interaction zone between $V$. fungicola and $A$. bisporus (bar, $1 \mu \mathrm{m}$ ); (d, e) details of the interaction site before penetration, showing signs of $A$. bisporus cell wall degradation (bars, $1 \mu \mathrm{m}$ ); $(f)$ penetration of $A$. bisporus by $V$. fungicola. Note disappearance of wall structure at penetration site (bar, $1 \mu \mathrm{m})$. 

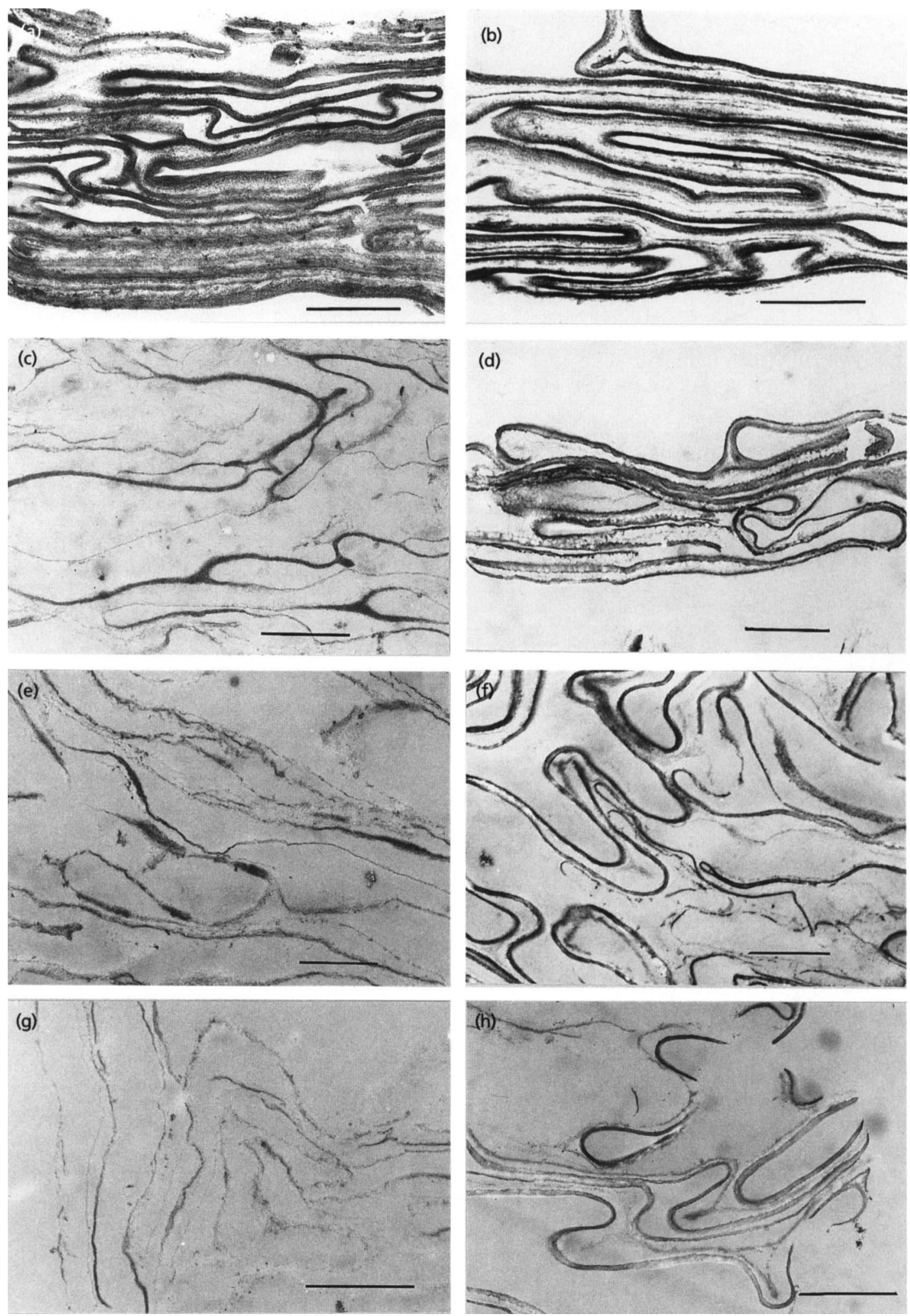

Fig. 5. Transmission electron micrographs of $A$. bisporus cell walls incubated with enzyme extracts of $V$. fungicola. (a, b) $A$. bisporus cell wall controls, $0 \mathrm{~h}$ and $72 \mathrm{~h}$ respectively; $(c, e, g)$ cell walls after 16,24 and $72 \mathrm{~h}$, respectively, of incubation with the enzyme extract of $V$. fungicola grown in medium containing $A$. bisporus cell walls as carbon source; (d, $f, h)$ cell walls after 16, 24 and $72 \mathrm{~h}$, respectively, of incubation with the enzyme extract of $V$. fungicola grown in medium containing fructose as carbon source. Bars, $1 \mu \mathrm{m}$. 
incubated with the enzyme extracts from medium containing fructose and that containing cell walls was $7.6 \%$ and $18.9 \%$, respectively; after $24 \mathrm{~h}$ it was $9.6 \%$ and $26.7 \%$; and after $72 \mathrm{~h}$ it was $16.7 \%$ and $40.0 \%$ (each value represents the mean of three separate determinations).

\section{DISCUSSION}

In the present work the production of enzymes secreted by $V$. fungicola growing on minimal synthetic medium supplemented with glucose, fructose, sucrose or $A$. bisporus fruit body cell walls as the carbon source has been studied, in an attempt to compare their hydrolytic effect on such walls with the in vivo effect of $V$. fungicola on $A$. bisporus fruit bodies. Some of the enzyme activities identified were endopolysaccharidases $(1,3-\beta$ glucanase, 1,6- $\beta$-glucanase, $1,4-\beta$-glucanase, $1,3-\alpha$-glucanase, 1,4- $\alpha$-glucanase, 1,4- $\beta$-xylanase and chitinase), disaccharases (chitobiosidase), exopolysaccharidases $(\beta$ $\mathrm{D}$-glucosidase, $\alpha$-D-glucosidase, $\beta$-D-xylosidase, $\beta$-Dmannosidase, and $N$-acetyl- $\beta$-D-glucosaminidase) and proteases. Some of these lytic enzymes, which are key enzymes in the lysis of cell walls of higher fungi, are produced by other organisms that are known to attack and parasitize fungi (Elad et al., 1982, 1985).

The results have shown that most of the enzyme activities produced by $V$. fungicola growing on $A$. bisporus walls are also present in the three other media tested, although in lesser amounts, suggesting their partial constitutive nature $-1,4-\beta$-glucanase was induced by cell walls but not by the other substrates. 1,3$\beta$-Glucanase seemed to be less affected by the carbon source than the other activities, showing high values in all the culture media. Cell walls promoted 1,6- $\beta$ glucanase production and constitutive enzyme levels were produced when the mycelium was incubated with fructose, glucose or sucrose. Data obtained suggest that enzyme activities might be subject to both induction and catabolite repression since they reach a maximum activity after $72 \mathrm{~h}$ and then drastically decrease, except for 1,3- $\beta$-glucanase and protease activities, which did not show significant differences after $3 \mathrm{~d}$ growth.

The fact that the production of most of the carbohydrolases and proteases was higher in the medium containing cell walls is not surprising since $A$. bisporus contains large amounts of different carbohydrates and proteins in its walls (García Mendoza et al., 1987a ; Mol \& Wessels, 1990). As this cell wall possesses a complex layered structure (García Mendoza et al., 1987b; Mol et al., 1990) the gradual action of the endopolysaccharidases could facilitate the subsequent action of the exopolysaccharidases.

On the other hand, PAGE results showed that $V$. fungicola presented different extracellular protein patterns when growing in medium containing cell walls or with the other carbon sources. Moreover, cultures grown in the cell wall medium gave a higher number of protein bands and some of them may correspond to other specific cell wall lytic activities not identified at present. 1,3- $\beta$-Glucanase and chitinase activities separated by native gel electrophoresis and identified by their specific tests were found to be composed of various isoforms. Obviously, $V$. fungicola produces different isoforms of both hydrolytic enzymes according to the composition of the growth medium, indicating that at least some of those isoforms are induced only in the presence of $A$. bisporus cell walls.

From all these results it can be concluded that the secretion of the enzymes in vitro is a good indicator of the kind of enzymes that the pathogen could produce and the role that they play in relation to disease.

Electron microscopy of the sequential enzymic digestion of the isolated $A$. bisporus cell walls showed significant differences between the enzyme extract obtained from cell walls medium and from fructose medium, suggesting that the presence of $A$. bisporus cell walls induces in $V$. fungicola the appropriate enzyme engineering to attack A. bisporus cell walls. The micrographs presented here show evidence that this degradation does not take place simultaneously and with the same intensity on both the outer and inner wall surfaces, although at the end of the process, most, and in some zones all, the wall polysaccharidic structure partially disappeared. This in vitro multistage wall degradation may be different than that in living cells in which other factors can limit the accessibility of the substrates to the enzymes, but in any case an important enzymic degradation seems to occur which produces softening of $A$. bisporus cell walls by the intercellular V. fungicola infection (Dragt et al., 1995) or the breakage of more sensitive points of this wall which permits intracellular penetration (Dragt et al., 1996).

The different behaviour of the A. bisporus living cells towards the $V$. fungicola enzymes could be due to particular architectural features of the cell wall related to the morphogenetic process, together with other factors such as the production of brown pigments (melanins), also suggested by Dragt et al. (1995), which can inhibit the action of the polysaccharide enzymes by producing resistant chitin-melanin complexes (Bull, 1970).

\section{ACKNOWLEDGEMENTS}

We thank E. Blanco for his excellent technical assistance in the electron microscopy. This work was carried out with the support of the Dirección General de Investigación Científica y Técnica (PB95-0078-C02-02) and the Comunidad Autónoma de Castilla-La Mancha (95/CH-31). Thanks are also given to Centro de Investigación, Experimentación y Servicios del Champiñon for supplying the $V$. fungicola strain and the $A$. bisporus fruit bodies.

\section{REFERENCES}

Avellán, M. A., García Mendoza, C. \& Novaes-Ledieu, M. (1986). Relationship between the presence of wall mucilage and the cellular disruption method employed in Agaricus bisporus tertiary mycelium. FEMS Microbiol Lett 34, 101-104.

Bartnicki-García, S. (1968). Cell wall chemistry, morphogenesis and taxonomy of fungi. Annu Rev Bacteriol 22, 87-108. 
Bradford, M. M. (1976). A rapid and sensitive method for quantitation of microgram quantities of protein utilizing the principle of protein-dye binding. Anal Biochem 72, 248-254.

Bull, A. T. (1970). Inhibition of polysaccharidases by melanin: enzyme inhibition in relation to mycolysis. Arch Biochem Biophys 137, 345-356.

Davis, B. J. (1964). Disc electrophoresis. II. Method and application to human serum proteins. Ann N Y Acad Sci 121, 404-427.

De la Cruz, J., Hidalgo-Gallego, A., Lora, J. M., Benitez, T., PintorToro, J. A. \& Llobel, A. (1992). Isolation and characterization of three chitinases from Trichoderma harzianum. Eur J Biochem 206, 859-867.

Dragt, J. W., Gells, F. P., Rutjens, A. J. \& Van Griensven, L. J. L. D. (1995). Resistance in wild types of Agaricus bisporus to the mycoparasite Verticillium fungicola var. fungicola. Mushroom Sci 14, 679-683.

Dragt, J. W., Gells, F. P., De Bruijn, C. \& Van Griensven, L. J. L. D. (1996). Intracellular infection of the cultivated mushroom Agaricus bisporus by the mycoparasite Verticillium fungicola var. fungicola. Mycol Res 100, 1082-1086.

Elad, Y., Chet, I. \& Henis, Y. (1982). Degradation of plant pathogenic fungi by Trichoderma harzianum. Can J Microbiol 28, 719-725.

Elad, Y., Lifshitz, R. \& Baker, R. (1985). Enzymatic activity of the mycoparasite Pythium nunn during interaction with host and non-host fungi. Physiol Plant Patbol 27, 131-148.

Garcla Mendoza, C., Avellán, M. A., Sanchez, E. \& Novaes-Ledieu, M. (1987a). Differentiation and wall chemistry of Agaricus bisporus vegetative and aggregated mycelia. Arch Microbiol 148, 68-71.

Garcla Mendoza, C., Sanchez, E. \& Novaes-Ledieu, M. (1987b). Differences in microfibrils in the walls of Agaricus bisporus secondary mycelium. FEMS Microbiol Lett 44, 161-165.

Kalberer, P. (1984). Some properties of extracellular proteolytic enzyme of Verticillium fungicola, a pathogen of the cultivated mushroom Agaricus bisporus. Phythopathol Z 110, 213-220.

McCreath, K. J. \& Gooday, G. W. (1992). A rapid and sensitive microassay for determination of chitinolytic activity. J Microbiol Methods 14, 229-237.
Matthews, C. T. (1983). The pathology and ecology of Verticillium fungicola (Preuss) Hassebrauk, pp. 39-71, 165-170. PhD thesis, University of Bath.

Michaels, T. J. (1973). Studies on the Verticillium disease of mushroom: extracellular hydrolases of Verticillium malthousei Ware and in vitro host-pathogen relationships, p. 52. MS thesis, University of Nevada.

Mol, P. C. \& Wessels, J. G. H. (1990). Differences in wall structure between substrate hyphae and hyphae of fruit body stipes in Agaricus bisporus. Mycol Res 94, 472-479.

Mol, P. C., Vermeulen, C. A. \& Wessels, J. G. H. (1990). Diffuse extension of hyphae in stipes of Agaricus bisporus may be based on a unique wall structure. Mycol Res 94, 480-488.

Nelson, N. J. (1957). Colorimetric analysis of sugars. Methods Enzymol 3, 85-86.

North, L. H. \& Wuest, P. J. (1993). The infection process and symptom expression of verticillium disease of Agaricus bisporus. Can J Plant Pathol 15, 74-80.

Pan, S. Q., Ye, X. S. \& Kué, J. (1989). Direct detection of $\beta(1,3)$ glucanase isozymes on polyacrylamide electrophoresis and isoelectrofocusing gels. Anal Biochem 182, 136-140.

Raper, C. A., Raper, J. R. \& Miller, R. E. (1972). Genetic analysis of the life-cycle of Agaricus bisporus. Mycologia 64, 1088-1117.

Riessig, J. L., Strominger, J. L. \& Leloir, L. F. (1955). A modified colorimetric method of the estimation of $\mathrm{N}$-acetylamino sugars. $J$ Biol Chem 27, 959-966.

Somogyi, M. (1952). Notes on sugar determination. J Biol Chem 195, 19-23.

Trigiano, R. N. \& Fergus, C. L. (1979). Extracellular enzymes of some fungi associated with mushroom culture. Mycologia 71, 908-917.

Trudel, J. \& Asselin, A. (1989). Detection of chitinase activity after polyacrylamide gel electrophoresis. Anal Biochem 178, 362-366. Ware, W. M. (1933). A disease of cultivated mushroom caused by Verticillium malthousei sp. nov. Ann Bot 47, 763-785.

Received 7 February 1997; revised 21 April 1997; accepted 23 May 1997. 